\title{
PERAN TOGAMAS (TOKOH AGAMA DAN MASYARAKAT) DALAM KEHIDUPAN SOSIAL KEAGAMAAN DI DESA BOTO SEMANDING TUBAN
}

\author{
Muslimin \\ Program Studi Pendidikan Agama Islam, Fakultas Tarbiyah IAINU Tuban \\ Email: muslimin12tbn@gmail.com \\ Fathul Amin \\ Program Studi Pendidikan Agama Islam, Fakultas Tarbiyah IAINU Tuban \\ Email: fathulamin@stitmatuban.ac.id
}

\begin{abstract}
Abstrak
Masalah penelitian ini menjelaskan tentang peran togamas (Tokoh Agama dan Masyarakat) dalam kehidupan sosial keagamaan di desa Boto Semanding Tuban. Dalam penelitian ini bertujuan (1) mendeskripsikan peran togamas dalam kehidupan sosial keagamaan di desa Boto Semanding Tuban (2) mendeskripsikan kehidupan sosial kegamaan masyarakat di desa Boto Semanding Tuban. Penelitian ini menggunakan metode deskriptif kualitatif dengan pendekatan fenomenologis melalui teknik analisis data kualitatif yaitu data aktual yang diperoleh kemudian disusun dan diklasifikasikan sesuai dengan sesuai dengan sub-sub pembahasan, kemudian diolah dengan data hasil wawancara, observasi, dan dokumentasi untuk memperoleh fakta-fakta dan fenomena yang ada di masyarakat desa Boto tentang peran togamas, kehidupan sosial keagamaan di masyarakat desa Boto Semanding Tuban.

Dari hasil penelitian dapat disimpulkan bahwa (1) kehidupan sosial kegamaan di desa Boto kecamatan Semanding kabupaten Tuban dapat dikatakan juga cukup baik dalam hal keagamaan, pendidikan, dan sosial kemasyarakatan serta dalam perekonomiannya cukup makmur dan sejahtera (2) peran togamas memilki peranan penting dalam pembinaan kehidupan sosial keagamaan masyarakat di desa Boto Semanding Tuban. Peran tokoh agama berperan untuk membina sikap religius dan tokoh masyarakat membangun etika sosial dalam hidup bermasyarakat
\end{abstract}

Kata Kunci: Tokoh Agama, Tokoh Masyarakat, Kehidupan Sosial, Keagamaan.

\section{PENDAHULUAN}

Pendidikan Agama memberi ajaran untuk dijadikan landasan berperilaku bagi pemeluknya, namun realitas dalam praktik kehidupan masyarakat tidak sedikit pula yang bertentangan dengan ajaran agama. Tambahan lagi acara-acara televisi tidak sedikit yang merusak moralitas bangsa, khususnya anak-anak, remaja dan orang tua yang strata pendidikannya rendah. Sekarang ini masalah moralitas dikalangan muda-mudi, khususnya pelajar dan mahasiswa sudah menjadi problema umum. Misalnya sering terjadi tindakan kriminal, asusila, hingga tindakan pembunuhan. Tidak hanya itu, pemakaian obat-obatan terlarang juga semakin banyak digunakan, adanya sex bebas dan masih banyak lagi. Bahkan sering kita lihat berita, bahwa ada ibu yang tega membuang darah dagingnya sendiri dikarenakan hubungan di luar nikah (DetikNews, Minggu 05 April 2020, 
16:29 WIB ). Secara logika, seharusnya kita tidak akan tega menyakiti apalagi sampai membunuh seseorang yang telah berjasa dan berarti di hidup kita. Namun faktanya, akhir-akhir ini banyak manusia yang tidak berpikir panjang dalam melakukan perbuatan yang dilarang tersebut. Salah satu yang memengaruhi manusia untuk melakukan hal tersebut dikarenakan kurangnya pendidikan yang diperoleh, khususnya pendidikan agama Islam.

Jika kita melihat kenyataan perilaku sosial orang Indonesia yang mayoritas beragama Islam ini, masih ada persoalan besar khususnya dalam hal moralitas masyarakat atau etika sosial. Realitas dalam kehidupan bermasyarakat bahwa ada perilaku moralitas yang tidak berlandaskan nilai-nilai ajaran Islam, seperti yang terjadi di negara-negara Barat pada umumnya. Menurut Riadi dkk (2017:9) "hasil seminar pendidikan agama Islam se-Indonesia pada 7 sampai 11 Mei 1960 di Cipayung Bogor menyatakan bahwa :

"Pendidikan Agama Islam adalah suatu bimbingan terhadap pertumbuhan rohani dan jasmani menurut ajaran Islam. Dari pernyataan para ahli tersebut dapat disimpulkan bahwa pendidikan agama Islam yang dimaksud dalam penelitian ini yaitu lebih banyak ditujukan kepada perbaikan sikap mental yang akan terwujud dalam amal perbuatan, baik bagi keperluan diri sendiri maupun orang lain."

Oleh karena itu, Pendidikan Agama Islam mempunyai arti dan peran penting dalam membentuk kepribadian manusia. Sebab dengan pendidikan agama ini manusia tidak diarahkan kepada pencapaian kebahagiaan hidup di dunia saja, tetapi juga untuk kebahagiaan hidup di akhirat. Dengan Pendidikan Agama Islam manusia diarahkan kepada perbaikan sikap mental yang akan terwujud dalam amal perbuatan, baik untuk keselarasan hubungan antara manusia dalam lingkup sosial, juga hubungan manusia dengan Tuhannya, serta tidak mudah tergoyahkan di tengah perubahan sosial yang semakin cepat seperti saat ini.

Menurut Nasution (1995:21) "kecepatan perubahan sosial dalam berbagai masyarakat berbeda-beda. Perubahan dalam masyarakat yang terpencil berjalan lambat, akan tetapi bila dengan terbukanya komunikasi dan transportasi daerah itu berkenalan dengan dunia modern, maka masyarakat ini akan berkembang dengan lebih cepat". Kehidupan masyarakat yang modern seperti sekarang ini, ditandai dengan ketersediaan berbagai fasilitas hidup yang memungkinkan manusia memanfaatkan kemajuan ilmu dan teknologi, untuk mencapai kebutuhan utamanya dengan mudah, peran agama di sini tetap diperlukan. Pengabaian terhadap tuntunan agama dalam kehidupan modern akan berakibat munculnya malapetaka bagi umat manusia secara meluas sebab manusia modern tanpa bimbingan agama akan bebas mengikuti kecenderungan nafsu semata. Masyarakat perkotaan yang modern cenderung mengabaikan arti pentingnya agama dalam mengisi sendi-sendi kehidupannya. Dan untuk masyarakat di pedesaan khusunya di desa Boto Semanding Tuban saat ini 
sudah terjadi perubahan yang signifikan di banding dengan dua puluh tahun yang lalu, ini merupakan sesuatu yang perlu di banggakan bagi masyarakat Boto dan sekitarnya.

Perlu kita ketahui bersama bahwa setiap manusia menginginkan perubahan kehidupan sosial keagamaan yang bermakna, baik untuk dirinya sendiri maupun orang lain. Kehidupan yang bermakna memberi kesadaran pada diri manusia bahwa keberadaannya diterima, serta dihargai oleh manusia lainnya. Hal semacam ini baru akan terjadi apabila manusia bekerja sama untuk mencapai suatu tujuan bersama, bahkan persaingan yang sifatnya memotivasi atau menambah etos sangat diperlukan dalam interaksi tersebut. Kaitannya dengan hal ini Tokoh Agama dan Masyarakat harus mampu untuk memberikan penerang kepada masyarakat bagaimana pola hidup bermasyarakat harus di kedepankan terutama dalam kehidupan bermasyarakat, agar terjadi sebuah suasana masyarakat yang guyub rukun, saling menghormati dan menghargai terhadap sesame. Maka dalam hal tersebut begitu pentingnya Peran seorang Tokoh Agama dan Masyarakat untuk bau membau bersatu dalam kebersamaan.

Perhatian Islam terhadap interaksi sosial masyarakat disebutkan dalam QS. Ali Imran [3] ayat 112 seperti berikut:

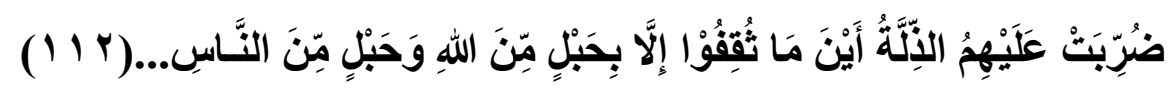
Artinya : Mereka diliputi kehinaan di mana saja mereka berada, kecuali jika mereka (berpegang) pada tali (agama) Allah dan tali (perjanjian) dengan manusia... (Q.S Ali Imron [3] :112).

Ayat tersebut menjelaskan bahwa untuk mencapai kemuliaan, manusia harus senantiasa memperhatikan dan menjaga hubungannya kepada Allah dan sesama manusia. Hal ini mengindikasikan bahwa kecintaan hamba terhadap Tuhannya didukung dan termanifestasi dalam kehidupan sosialnya. Dipertegas dalam hadits Rasulullah SAW berikut:

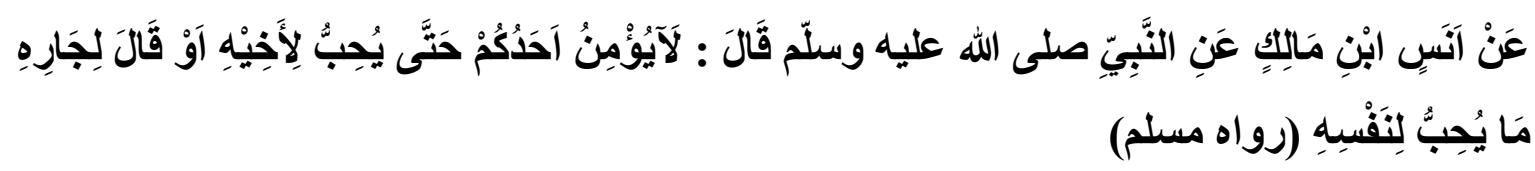

Dari Anas bin Malik RA., Rasulullah SAW bersabda: "Belum sempurna iman seseorang, sebelum dia mencintai saudaranya atau tetangganya sebagaimana cintanya terhadap dirinya sendiri” (HR Muslim).

Hadits ini tidak hanya menggambarkan sikap semestinya dalam berinteraksi sosial, melainkan menuntut adanya kondisi batin berupa kecintaan dalam melandasi interaksi sosial masyarakat. Sehingga hubungan yang terjalin bukan sekedar relasi kontraktual, melainkan relasi 
berbasis Ilahiah dengan menghasilkan manfaat duniawi, dari sini kemudian diasumsikan pentingnya pendidikan Islam dalam interaksi sosial masyarakat (Arsyad, 2019).

Pendidikan Islam mempunyai mandat dan tanggung jawab untuk merealisasikan terwujudnya potret manusia yang memiliki kapasitas yang tidak hanya berorientasi kepada permasalahan ukhrawi saja tetapi juga harus terintegrasi dalam persoalan duniawi, seperti ilmu pengetahuan, teknologi, seni, budaya, sosial kemasyarakatan dan sebagainya (Khair, 2013). Pandangan ini menghendaki pengahayatan agama bukan hanya mengarah pada kehidupan ukhrawi, akan tetapi menjadikan kehidupan dunia sebagai ladang untuk mencari bekal di akhirat kelak atau memajukan kehidupan dunia tanpa tenggelam dalam kenikmatan sesaat. Menurut Anwar dkk (2017:111-112) "jelaslah bahwa manusia membutuhkan bimbingan dan petunjuk yang benar dan bernilai mutlak untuk meraih kebahagiaan hidup jasmani dan rohani, dunia dan akhirat. Untuk itu di samping akal, Allah juga memberikan anugerah lain kepada manusia sebagai pembimbing gerak akal yaitu agama".

Dr. Kaelany juga menjelaskan adanya dua prinsip yang perlu kita perhatikan, yaitu: Pertama: Manusia dilarang menciptakan agama, termasuk system ibadah dan tata caranya, karena masalah agama dan ibadah adalah hak mutlak Allah dan para Rasul-Nya yang ditugasi menyampaikan agama itu kepada masyarakat. Maka menciptakan agama dan ibadah adalah bid'ah. Sedang setiap bid'ah adalah sesat. Kedua: Adanya kebebasan dasar dalam menempuh hidup ini, yaitu hal-hal yang berkaitan dengan masalah mu'amalah, seperti pergaulan hidup dan kehidupan dalam masyarakat dan lingkungan, yang dikaruniakan Allah kepada umat manusia (Bani Adam) dengan batasan atau larangan tertentu yang harus dijaga. Sebaliknya melarang sesuatu yang tidak dilarang oleh Allah dan Rasul-Nya adalah bid'ah. (Kaelany, 2009:71)

Dalam menjalankan keseharian, penting bagi kita untuk mengingat dua prinsip di atas. Ibadah tidak dapat dilakukan dengan sekehendak hati kita karena semua ketentuan dan aturan telah ditetapkan dalam Al-Qur'an dan Sunnah, serta contoh dan tatacaranya telah diajarkan oleh Rasulullah SAW semasa hidupnya. Melakukan sesuatu dalam ibadah, yang tidak ada disebutkan dalam Al-Qur'an dan Sunnah berarti melakukan sesuatu yang tidak diperintahkan oleh Allah SWT, dan ini sungguh merupakan perbuatan yang sesat.

Perlu kita mengetahui di masyarakat desa Boto Semanding Tuban sendiri merupakan masyarakat pedesaan. Jarak tempuh dengan kota tuban berjarak $\pm 10 \mathrm{~km}$. Kalau kita melihat sejarah berdiri atau adanya desa Boto yang paling populer adalah pada saat Pemerintahan Kesultanan Demak ada sebuah Dukuh yang bernama dukuh Pohwagah. Dan dukuh tersebut dipimpin oleh seorang tokoh yang bernama Mbah Kasiman atau yang lazim disebut Mbah Buyut Rumpak yang dimakamkan di Pekuburan Kramat. Dalam masa Kepemimpinannya Mbah Rumpak mempunyai 
sebuah usaha yaitu pembuatan Batu Bata (dalam bahasa jawa Boto) yang konon ceritanya Batu Bata tersebut di setor ke Demak untuk mendirikan masjid di sana. Suatu hari dalam menjalankan Syi'arnya Kanjeng Sonan Kalijogo lelaku dari Kesultanan Demak menuju ke Jawa Bagian Timur dan Kebetulan singgah di Padepokan Mbah Kasiman. Melihat Jasa-jasa dari Mbah Kasiman yang ikut andil dalam pembangunan di Demak, maka Sultan Demak lewat kanjeng Sunan Kali Jogo menobatkan Mbah Kasiman yang semula Pemimpin Pedukuhan menjadi petinggi desa dan dukuhan dimana mbah Kasiman memimpin akhirnya oleh Kanjeng Sunan Kali Jogo dinamakan Desa Boto karena dukuh tersebut sebagai sentral Pembuatan Batu Bata.

Dalam Kepemimpinan Mbah Kasiman sepertinya tidak ada sejarah yang menceritakan siapa penerus beliau. Baru sejak Tahun 1924 sampai sekarang diketahui pemimpinan Desa Boto Kecamatan Semanding Kabupaten Tuban. Dan Sejak tahun itulah Desa Boto telah mengalami pergantian kepemimpinan (Kepala Desa) sebagai berikut :

* Tahun 1924 - 1949, Desa Boto dipimpin oleh Yaidin

* Tahun 1950 - 1965, Desa Boto dipimpin oleh Sahit

* Tahun 1966 - 1974 Desa Boto dipimpin oleh Suratmin

* Tahun 1974 - 1989, Desa Boto dipimpin oleh Pasrun

* Tahun 1990 - 1991 Desa Boto Di PJ oleh Djanji Mansyur

* Tahun 1992 - 2000, Desa Boto dipimpin oleh Muksin

* Tahun 2001 - 2006, Desa Boto dipimpin oleh Sutarno

* Tahun 2007 - 2013, Desa Boto dipimpin oleh Muksin

* Tahun 2013 - 2019, Desa Boto dipimpin oleh Hartono

* Tahun 2019 sampai 6 Tahun kedepan dipimpin oleh Handoko Mulyo Utomo

Berdasarkan uraian tersebut di atas, maka peran togamas dalam kehidupan sosial keagamaan di desa boto semanding tuban harus memberikan dampak positif dalam kehidupan di masyarakat.

Berdasarkan Uraian tersebut di atas, maka tujuan dalam jurnal ini adalah 1). Untuk Mendeskripsikan Peran Togamas Dalam Kehidupan Sosial Keagamaan Di Desa Boto Semanding Tuban; 2). Untuk mendeskripsikan Kehidupan Sosial Keagamaan Masyarakat Desa Boto Semanding Tuban.

\section{Kehidupan Sosial}

Pengertian kehidupan sosial menurut Herdiana (2016) "sebuah kehidupan disebut kehidupan sosial jika di sana ada interaksi antara individu satu dengan individu lainnya, dan dengannya terjadi komunikasi yang kemudian berkembang menjadi saling membutuhkan kepada sesame ada dua kehidupan sosial yang secara umum yaitu kehidupan sosial di pedesaan dan kehidupan sosial di 
perkotaan. Namun masyarakat pedesaan dan masyarakat perkotaan memiliki perbedaan yang nampak". Soekanto (2010:143) menjelaskan ciri-ciri pada masyarakat pedesaan dan perkotaan sebagai berikut:

Masyarakat pedesaan pada umumnya memiliki ciri sebagai berikut: (a) Warga memiliki hubungan yang lebih erat; (b) sistem kehidupan biasanya berkelompok atas dasar kekeluargaan; (c) umumnya hidup dari hasil pertanian; (d) golongan orang tua memegang peranan penting; (e) dari sudut pemerintahan, hubungan antara penguasa dan rakyat bersifat informal; (f) perhatian masyarakat lebih pada keperluan utama kehidupan; (g) kehidupan keagamaan lebih kental; dan (h) banyak berurbanisasi ke kota karena ada faktor yang menarik dari kota. Sedangkan masyarakat perkotaan memiliki ciri; (a) Jumlah penduduknya tidak tentu; (b) bersifat individualistis; (c) pekerjaan lebih bervariasi, lebih tegas batasannya dan lebih sulit mencari pekerjaan; (d) perubahan sosial terjadi secara cepat, menimbulkan konflik antara golongan muda dengan golongan orang tua; (e) perhatian lebih pada penggunaan kebutuhan hidup yang dikaitkan dengan masalah prastise; (f) kehidupan keagamaan lebih longgar; dan (g) banyak imigran yang berasal dari daerah dan berakibat negatif di kota, yaitu pengangguran, naiknya kriminalitas dan lain-lain.

Berdasarkan pendapat di atas, dapat disimpulkan bahwa kehidupan sosial adalah kehidupan yang di dalamnya menyangkut unsur-unsur sosial (interaksi antara individu dengan individu, individu dengan kelompok atau kelompok dengan kelompok).

\section{Makna dan Tujuan Hidup}

Pada dasarnya tujuan hidup manusia adalah untuk memperoleh kebahagiaan di dunia maupun di akhirat, sementara kewajiban atau tugas hidup manusia menurut Al-Qur'an adalah mengabdi atau beribadah kepada Allah (Supadie dkk, 2015:184). Manusia diciptakan Allah tidak lain adalah agar mengabdikan dirinya kepada-Nya. Allah berfirman dalam QS. Adz-Dzariyat [51] ayat 56 :

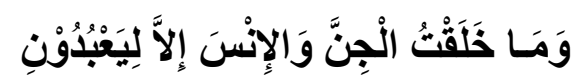

Artinya : Aku ciptakan jin dan manusia kecuali untuk mengabdi kepadaku (QS. Adz-Dzariyat [51]: 56).

Ayat di atas secara tegas menolak pernyataan lain bahwa kehadiran manusia di dunia bersifat kebetulan (ada dengan sendirinya). Begitu pula, ayat di atas menolak pandangan bahwa manusia diciptakan untuk mengeksploitasi alam semesta beserta isinya, sehingga merasa biasa saja saat manusia berbuat kerusakan di muka bumi. 
Allah menghendaki agar kehidupan manusia di dunia ini diarahkan untuk mengabdi kepadaNya. Untuk mewujudkan kehendak tersebut, Allah telah mengokohkan dalam diri manusia kesediaan untuk menyembah-Nya (QS. Al-A'raf [7]: 172):

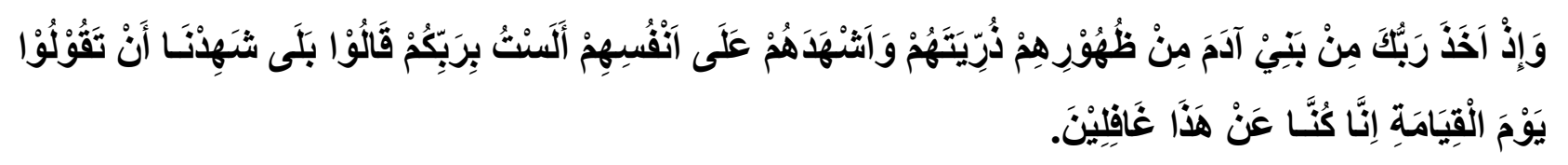

Artinya : Dan (ingatlah), ketika Tuhanmu mengeluarkan keturunan anak-anak Adam dari sulbi mereka dan Allah mengambil kesaksian terhadap jiwa mereka (seraya berfirman) : "Bukankah Aku ini Tuhanmu?" Mereka menjawab: “Betul (Engkau Tuhan kami), kami menjadi saksi”. (Kami lakukan yang demikian itu) agar di hari kiamat kamu tidak mengatakan: "Sesungguhnya kami (bani Adam) adalah orang-orang yang lengah terhadap ini (Ke-Esaan Tuhan)”.

\section{Pengertian Masyarakat}

Menurut Khoiriyah (2014:105-106) “Masyarakat berasal dari bahasa Arab Musyarak yang artinya bersama-sama, kemudian menjadi masyarakat yang artinya berkumpul bersama, hidup bersama dengan saling berhubungan". Masyarakat adalah tempat hidup bersama dari individuindividu yang menjalin hubungan interaksi antara yang satu dengan lainnya. Mac Iver dan Page dalam Supardan (2015:27-28) mengemukakan bahwa, "Masyarakat ialah suatu sistem dari kebiasaan dan tata cara, dari wewenang dan kerja sama antara berbagai kelompok dan penggolongan, dari pengawasan tingkah laku serta kebebasan-kebebasan manusia. Keseluruhan yang selalu berubah ini kita namakan masyarakat". Masyarakat merupakan jalinan hubungan sosial dan masyarakat selalu berubah-ubah atau bersifat dinamis. Selo Soemardjan dalam Supardan (2015:28) menyatakan bahwa "Masyarakat adalah orang-orang yang hidup bersama dan menghasilkan kebudayaan". Dalam kehidupan bermasyarakat, kebudayaan merupakan unsur penting karena mengandung nilai-nilai dan norma-norma sosial. Sedangkan Khoiriyah (2014:70) menyatakan bahwa "masyarakat merupakan pendukung kebudayaan". Berbicara tentang kebudayaan yang ada di dalam masyarakat, hubungan antara individu bukanlah sepihak saja, akan tetapi memiliki hubungan timbal balik.

Kebudayaan memengaruhi individu dan individu juga memengaruhi kebudayaan sehingga terjadi perubahan sosial. Dengan nilai-nilai kebudayaan anggota masyarakat mengetahui apakah yang layak, pantas, baik dan seharusnya. Nilai-nilai bisa berupa positif dan negatif. Dengan normanorma, aturan-aturan kelakuan bisa diterima oleh masyarakat (Khoiriyah, 2014:107). "Al-Syaibani 
dalam Nata (2014:57) berpendapat bahwa masyarakat adalah sebagai tempat dimana individu dan kelompok berinteraksi, menjalin hubungan sesamanya". Dalam menjalin hubungan sosial, tidak boleh bersikap diskriminatif, kita harus memperlakukan setiap orang dengan baik. Khoiriyah (2014:106) menjelaskan bahwa "sebagai makhluk sosial, manusia hidup dalam hubungannya dengan orang lain dan bergantung pada orang lain, manusia hidup menjadi bagian dari masyarakat berarti ada interaksi dengan orang sekitar".

Sedangkan Soekanto (2010:55) berpendapat bahwa "bentuk umum dalam proses sosial adalah interaksi sosial, karena interaksi sosial merupakan syarat utama terjadinya aktivitas-aktivitas sosial... interaksi sosial merupakan hubungan-hubungan sosial yang dinamis, menyangkut hubungan secara perorangan, antara kelompok-kelompok manusia, maupun antara perorangan dengan kelompok manusia". Soekanto (2010:58) menjelaskan "suatu interaksi sosial tidak akan mungkin terjadi apabila tidak memenuhi dua syarat yaitu adanya kontak sosial dan adanya komunikasi”. Artinya adanya kontak sosial dapat berlangsung dalam tiga bentuk yaitu antara individu dengan individu, individu dengan kelompok, dan kelompok dengan kelompok. Sedangkan adanya komunikasi maksudnya seseorang memberi arti pada perilaku orang lain, dan orang yang bersangkutan kemudian memberikan reaksi terhadap perilaku tersebut.

\section{METODOLOGI PENELITIAN}

Pendekatan di dalam penelitian ini berdasarkan orientasi teoritis yaitu pendekatan fenomenologis. Menurut Moleong (2007:31) pendekatan fenomenologis adalah pendekatan yang didasarkan atas pemahaman fenomena yang terjadi melalui penggambaran secara holistik yang penarikan kesimpulannya berdasarkan induktif dan berorientasi pada proses serta melalui pengukuran objektif dengan analisis non-numerikal. Artinya peneliti mengamati fenomena sosial yang terjadi di masyarakat desa Boto yang berkaitan dengan begitu dahsyatnya arus perubahan masyarakat yang semula merupakan pedesaan pelosok yang masih minim masyarakatnya mengamalkan agama, dan masih mengabaikan tatanan agama yang ada yaitu agama islam. Dari pengamatan fenomena sosial tersebut, peneliti mendapati data penelitian tentang kehidupan sosial keagamaan dan temuan penelitian tentang peran togamas dalam kehidupan sosial keagamaan yang begitu kental dan mengena, yang menurut peneliti menjadi salah satu alat untuk meluruskan kehidupan bermasyarakat yang lebih baik.

Sedangkan berdasarkan jenis datanya, jenis penelitian ini adalah penelitian kualitatif. LP3M STITMA (2019:32-33) menjelaskan bahwa penelitian kualitatif adalah penelitian yang berusaha mengungkapkan gejala secara menyeluruh dan sesuai dengan konteks (holistik-kontekstual) melalui pengumpulan data dari latar alami dengan ciri bersifat deskriptif dan analisa induktif yang 
memanfaatkan diri peneliti sebagai instrumen kunci. Artinya peneliti berusaha untuk mencari data berdasarkan fenomena yang ada di masyarakat secara menyeluruh dan menemukan temuan penemuan dalam konteks peran togamas dalam kehidupan social keagaman di Desa Boto Semanding Tuban. Adapun metode di dalam penelitian ini adalah metode deskriptif-kualitatif. Artinya peneliti mendeskripsikan semua data yang tergambar dalam fenomena sosial masyarakat desa Boto dan temuan penelitian tentang peran Togamas yang harus hadir di tengah-tengah masyarakat dan pendeskripsiannya hanya dalam bentuk kata-kata, kalimat-kalimat, dan bukan angka-angka.

Dalam hal ini peneliti meneliti di Desa Boto Kecamatan Semanding Kabupaten Tuban dan waktu Penelitian ini dimulai tanggal 15 September 2020 sampai 15 Desember 2020.

\section{Sumber Data Penelitian}

Moleong (2017:157) menjelaskan bahwa sumber data utama dalam penelitian kualitatif ialah kata-kata dan tindakan, selebihnya adalah data tambahan seperti dokumentasi dan lain-lain. Sumber data yang digunakan dalam penelitian ini terbagi atas dua data:

\section{Sumber Data Utama (Primer)}

Kata-kata dan tindakan orang yang diamati atau di wawancarai merupakan sumber data utama. Data tersebut berupa sikap atau perilaku, dan aktivitas masyarakat yang berada di desa Boto. Pencatatan sumber data utama dilakukan melalui wawancara dan observasi. Dalam hal ini peneliti memperoleh data dari hasil wawancara dan observasi, antara lain wawancara dengan masyarakat desa Boto yaitu dari tokoh agama, tokoh masyarakat, pemerintah desa, perangkat dan beberapa pihak.

\section{Sumber Data Tambahan (Sekunder)}

\section{1). Sumber Tertulis}

Sumber tertulis walaupun dikatakan bahwa sumber di luar kata dan tindakan merupakan sumber ke dua, jelas hal itu tidak bisa diabaikan. Sumber data tertulis dalam penelitian ini adalah bukubuku, jurnal, dan internet yang berkenaan dengan penelitian ini.

\section{2). Foto atau Dokumentasi}

Sekarang ini foto semakin banyak digunakan sebagai alat untuk keperluan penelitian kualitatif, karena dapat dipakai dalam berbagai keperluan. Foto-foto yang dapat memberi gambaran tentang kegiatan Kehidupan sosial keagamaan di desa Boto. Foto yang digunakan diambil oleh peneliti sendiri dan teman. 


\section{Prosedur Pengumpulan Data}

Di dalam mengumpulkan data ini, peneliti menggunakan prosedur-prosedur yang terbagi sebagai berikut:

\section{1). Prosedur Awal}

Pada prosedur ini, peneliti melakukan persiapan penelitian dengan dua jenis kegiatan yaitu penyusunan judul dan pelaksanaan. Penyusunan judul tanggal 01 Oktober 2020 dan pelaksanaan 05 Oktober sampai 25 Desember 2020.

\section{2). Prosedur Pelaksanaan}

Di dalam melaksanakan penelitian ini, peneliti mengumpulkan data dengan menggunakan teknik observasi, wawancara, dan dokumentasi.

\section{a). Observasi}

Menurut Moleong (2017:174) metode ini digunakan dengan cara melakukan pengamatan dan pencatatan secara sistematik terhadap segala bentuk fenomena. Observasi adalah salah satu cara atau teknik dalam penelitian untuk mendapatkan hasil sebuah penelitian. Dengan observasi ini peneliti ingin mendapatkan hasil yang benar-benar utuh dari segala dimensi. Adapun kegiatan pengamatan yang dilakukan dalam penelitian ini yaitu:

1) Mengamati sikap moral, religi, sosial dan kebudayaan untuk mengetahui peran togamas dalam kehidupan sosial keagamaan di desa Boto Semanding Tuban.

2) Mengikuti kegiatan yang dilakukan untuk mengetahui isi kegiatan

\section{b). Wawancara}

Wawancara adalah percakapan dengan maksud tertentu. Percakapan itu dua pihak yaitu pewawancara yang mengajukan pertanyaan dan terwawancara yang memberikan jawaban atas pertanyaan itu (Moleong, 2017:186). Dalam wawancara ini, peneliti tentunya menggali informasi dari warga desa Boto sendiri, terutama dari tokoh agama, masyarakat dan pemerintah desa Wadung, juga dari masyarakat Badung pada umumnya.

\section{c). Dokumentasi}

Moleong (2017:217) berpendapat bahwa metode dokumentasi adalah mencari data mengenai hal-hal yang berupa catatan, transkip, buku, surat kabar, majalah, prasasti, notulen rapat, lengger, agenda dan sebagainya. Dibandingkan dengan metode lain, maka metode ini tidak begitu sulit dalam artian apabila ada kekeliruan sumber datanya masih tetap, belum berubah. Perolehan data pelengkap dengan teknik dokumentasi juga digunakan dalam penelitian ini dengan menggunakan alat bantu, diantaranya data berupa foto yang digunakan diambil oleh peneliti di lokasi penelitian yaitu di desa Boto, diantaranya adalah foto kegiatan keagamaan, sosial dan kegiatan wawancara. Selain foto-foto dari sumber pribadi, peneliti juga mendapatkan dokumentasi berupa foto yang 
dimiliki oleh orang lain. Dan dokumen, yang digunakan berupa dokumen mengenai data yang dimiliki oleh desa Boto.

3). Prosedur Akhir

Pada prosedur akhir ini, peneliti mulai mengumpulkan data hasil observasi, dan wawancara kemudian mulai memastikan keabsahan data yang sudah dikumpulkan dengan triangulasi. Artinya, untuk memastikan keabsahan data, peneliti berdiskusi dengan narasumber wawancara, teman sejawat.

\section{Analisis Data}

Menurut Moleong (2017:248) "analisis data kualitatif adalah upaya yang dilakukan dengan jalan bekerja dengan data, mengorganisasikan data, memilah-milah menjadi satuan yang dapat dikelola, mengsistensiskannya, mencari dan menemukan pola, menemukan apa yang penting dan apa yang dipelajari serta memutuskan apa yang dapat diceritakan kepada orang lain”. Sedangkan Karsadi (2018:89) menjelaskan bahwa "berkaitan dengan analisis data kualitatif, menurut Bogdan, analisis data adalah proses mencari dan menyusun secara sistematis data yang diperoleh darai hasil wawancara, catatan lapangan, dan bahan-bahan lain sehingga dapat mudah dipahami dan temuannya dapat diinformasikan kepada orang lain”.

Dari berbagai referensi terdapat beberapa model analisis data kualitatif, salah satunya yaitu analisis data model Miles dan Huberman. Karsadi (2018:89-90) memaparkan bahwa "analisis data kualitatif model ini ada tiga kegiatan yang dilakukan oleh peneliti setelah pengumpulan data, yakni reduksi data, penyajian data, dan penarikan kesimpulan”, dapat dilihat pada gambar berikut

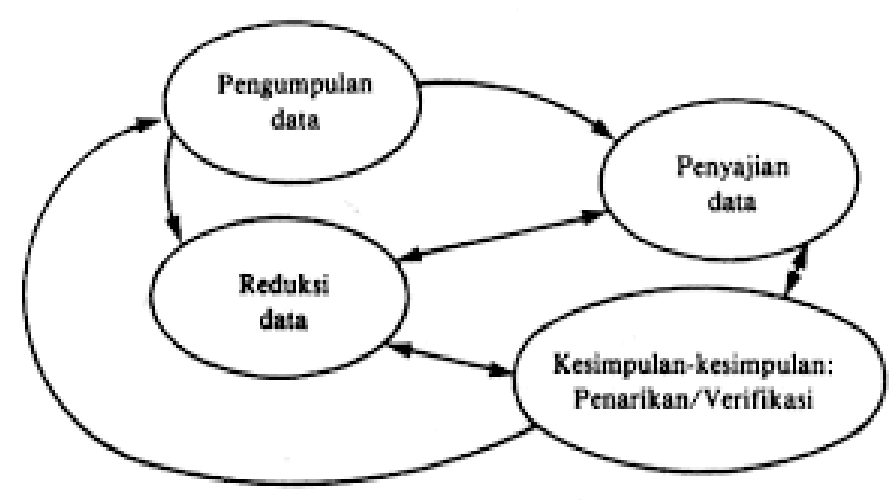

\section{Gambar ; Model Analisis Interaktif Miles dan Huberman}




\section{1). Data Reduction (Reduksi Data)}

Dimaksudkan untuk mereduksi data yang jumlahnya banyak yang sifatnya masih kasar, mentah dan berserakan dari data yang dikumpulkan di lapangan menjadi terorganisir dan tersistematisasi, terseleksi mana yang perlu digunakan dan mana yang perlu diabaikan, terseleksi data mana yang relevan dan utama serta mana yang hanya sebagai penunjang sehingga datanya menjadi fokus dan terarah.

\section{2). Data Display (Penyajian Data)}

Dimaksudkan bahwa agar data yang terorganisir, tersistematisasi, sederhana, fokus, dan terarah, kemudian ditampilkan dan disajikan dalam bentuk teks naratif yang memiliki arti, sehingga mudah dipahami dan dimengerti. Penyajian data ini juga dimaksudkan untuk pendeskripsian data yang sudah fokus dan terarah untuk mendeskripsikan temuan di lapangan, baik melalui wawancara, observasi maupun catatan lapangan lainnya.

3). Conclusions: Drawing/verifying (Penarikan Kesimpulan/Verifikasi)

Dimaksudkan agar setelah reduksi data atau penyajian data maka langkah selanjutnya dilakukan verifikasi secara tepat, cermat, dan teliti oleh peneliti, maka baru disusun kesimpulan yang masih sementara dan dilakukan verifikasi secara berkesinambungan, sehingga pada akhirnya disusun kesimpulan akhir. Kesimpulan akhir ini ditujukan untuk menjawab semua masalah yang menjadi fokus penelitian atau masalah penelitian (Karsadi, 2018:89-90).

\section{Validasi Temuan Penelitian}

Seperti yang sudah peneliti bahas dalam prosedur akhir di atas, bahwa dalam penelitian ini untuk memastikan keabsahan data yang sudah dikumpulkan, peneliti menggunakan suatu teknik yaitu dengan cara Triangulasi. Moleong (2017:330) mengatakan "triangulasi merupakan teknik pemeriksaan keabsahan data yang memanfaatkan sesuatu yang lain di luar data itu untuk keperluan pengecekan atau sebagai pembanding terhadap data itu. Teknik triangulasi yang paling banyak digunakan ialah pemeriksaan melalui sumber lainnya".

Artinya, dalam penelitian ini untuk memastikan keabsahan data, peneliti melakukan diskusi langsung dengan narasumber wawancara yakni dengan bapak H. Nafi'udin dan bapak Syamsul Hadi, S.Ag beliau selaku tokoh agama, Handoko Mulyo Utomo selaku kepala desa Boto, Nursyam selaku Tokoh masyarakat Umum, bapak Sutrisno selaku Kesra desa Boto, Ibu Siti Sofiatun salah satu ustadzah di TPQ Nurul Huda dan Ustadz Sadikin pengelola TPQ Al Ihlas. 


\section{HASIL DAN PEMBAHASAN}

Kehidupan Sosial keagamaan di desa Boto yang melewati proses panjang dan penuh cerita menjadikan daya tarik tersendiri. Maka dari itu untuk mengatasi permasalahan dalam kehidupan sosial, salah satu cara yang dapat ditempuh yaitu dengan cara mengoptimalkan peran togamas dalam kehidupan sosial keagaman, baik di lingkungan keluarga, lingkungan sekolah, atau di lingkungan masyarakat sebagai berikut:

\section{1). Di Lingkungan Keluarga}

Lingkungan keluarga merupakan lingkungan pendidikan pertama yang diperoleh anak, oleh karena itu keluarga khususnya orang tua sangatlah berpengaruh dalam memberikan pendidikan agama yang baik untuk anaknya. Anak harus dirawat dengan baik, disayang, dan dididik dengan pendidikan yang baik khususnya pendidikan agama Islam. Dilihat dari segi kualitas pendidikan agama di lingkungan keluarga, masyarakat desa Boto memang masih perlu ditingkatkan lebih dalam, seperti yang diungkapkan oleh Bapak Nursyam salah satu Tokoh Masyarakat di desa Boto pada hari Senin tanggal 05 Oktober 2020 berikut:

Anak-anak sekarang beda dengan anak-anak jaman dulu yang berkaitan dengan tatakrama atau orang jawa mengatakan (Unggah ungguh) itu mengkawatirkan dan orang tua sekarang ini mayoritas kurang memperhatikan hal tersebut, bahkan terkadang anak suka berbicara kotor (tidak pantas) dan anak sekarang lebih suka main Handphone. Sebagian orang tua berpendapat bahwa itu menjadi alternatif supaya anaknya mau dan tetap di rumah.

Hal senada juga di jelaskan oleh Bapak Sutrisno, salah satu perangkat desa bagian Kesra di desa Boto Semanding Tuban hari Selasa tanggal 06 Oktober 2020 sebagai berikut:

Sebagai Orang tua kurang memperhatikan pendidikan anak khususnya pendidikan agama di lingkungan keluarga, anak menjadi kurang pengawasan apalagi dalam pendidikan agamanya. Anak kecil sekarang banyak yang sudah dibiasakan pakai Handphone. Anak yang terbiasa main Handphone akan biasanya sering lupa waktu, sudah waktunya ngaji masih sibuk main game, waktu sholat masih juga main game. Seharusnyakan dibiasakan menghargai waktu untuk bisa di guanakan untuk belajar dan mengaji.

Dari ke dua pendapat diatas, dapat diambil kesimpulan bahwa pendidikan agama Islam di lingkungan keluarga pada masyarakat desa Boto ini harus lebih ditingkatkan dan diperhatikan lagi, karena anak merupakan generasi penerus, jadi orang tua sangat berperan dalam mendidik anaknya khususnya dalam segi pendidikan agama. Dengan cara membiasakan membaca Al-Qur'an di rumah 
bukan hanya saat di TPQ saja, ikut sholat berjamaah dan bersikap sopan santun ,menghormati saudara yang lebih dan menyayangi yang lebih muda.

2). Di Lingkungan Pendidikan Islam

Di desa Boto kecamatan Semanding kabupaten Tuban ini terdapat juga lembaga keagamaan yaitu TPQ \& Diniyah Ar-Rohman, TPQ Al Ihlas, TPQ Nurul Huda dan Majlis Taklim Nurul Huda. Dengan adanta beberapa Lembaga keagamaan diharapkan mampu untuk menyiapkan generasi yang unggul dan relegius dan melatih perkembangan daya pikirnya dengan memberikan materi yang sesuai dengan tingkat usia dan kematangan seseorang. Anak yang masih kecil pun tentunya cara mendidiknya berbeda dengan orang yang lebih dewasa, jadi lebih halus sehingga anak mudah ingat dan dapat menjadi teladan yang baik dalam kehidupan. Di lingkungan pendidikan ini peran guru atau ustadz sangatlah memengaruhi perkembangan pendidikan agama anak. Seperti yang diungkapkan oleh Ibu Siti Sofiatun, S.Pd selaku Ustadzah di desa Boto pada hari Rabu tanggal 21 Oktober 2020 sebagai berikut:

Kegiatan keagamaan harus di mulai dari Usia Dini dan di lanjut usia remaja. Saat ini Pendidikan agama di desa Boto ini sudah cukup baik, dan kalau untuk pendidikan anak usia dini di Desa Boto ada KB PKK Tunas Melati dan TK Muslimat NU 05 ini juga memberikan sumbangsih dan perkembangan yang signifikan. Dari segi kegiatan, pendidikan agama di KB dan TK ini, anak-anak selalu dibiasakan bersalaman atau mengucapkan salam ketika bertemu ibu guru, berdo'a sebelum melakukan kegiatan, meminta maaf jika melakukan kesalahan.

Hal senada juga di jelaskan Ustadz Sadikin Kamis tanggal 22 Oktober 2020 juga memaparkan sebagai berikut:

Nilai Pendidikan Agama Islam dalam lingkungan sekolah sekarang berbeda, dulu kan murid itu sopan terhadap guru misalnya saja kalau ada guru rawuh di sekolah, muridmurid itu seakan berlomba-lomba untuk bersalaman tapi sekarang ini sikap murid terhadap gurunya malah seperti ke temannya sendiri. Tapi bukan berarti semua murid seperti itu, tapi fakta tersebut sekarang sering kita jumpai di lembaga-lembaga seperti sekolah.

Dari ke dua penjelasan tersebut diatas dapat diambil kesimpulan bahwasanya pendidikan agama Islam di lingkungan sekolah pada masyarakat desa Boto ini secara umum sudah cukup baik, namun masih tetap perlu adanya bimbingan agar dapat meningkatkan pendidikan agama sehingga nilai-nilainya dapat tertanam dan berguna untuk menjalankan kehidupan bermasyarakat. 


\section{3). Di Lingkungan Masyarakat}

Lingkungan ini juga sangat memengaruhi perilaku seseorang dalam kehidupan sehariharinya. di desa Boto terdapat 1 masjid yaitu Masjid Nurul Huda dan ada 12 musholla. Lingkungan masyarakat yang masih menjaga tradisi agama dengan baik pastinya akan memengaruhi kehidupan seseorang, dan lingkungan yang kurang mementingkan agama tentu saja sangat memengaruhi sikap seseorang dalam kehidupannya. Seperti yang dijelaskan oleh salah satu tokoh agama di desa Boto ini yaitu bapak H. Nafi'udin pada hari Jum'at tanggal 06 November 2020 sebagai berikut:

Kehidupan sosial keagamaan Di desa Boto masih tetap bisa menjaga tradisi keagamaan meski di era yang semakin modern seperti saat ini.Itu semua tidak terlepas dari peran Tokoh agama dan tokoh masyarakat dalam menjaga Ukhuwah di masyarakat Boto. Kegiatan Sosial keagamaan banyak sekali misalnya Maulid nabi, isro’ miroj, Santunan, Yasinan, tahlil dan lain-lain. Saat ini jamaah Yasin Tahlil Nurul Huda Boto sebagai pelopor dan penggerak masyarakat dalam kehidupan social keagamaan. Ada juga jamaah ibu-ibu Muslimat dan Fatayat NU. Kalau dari kuantitas saat berkegiatan 20 sampai 60 jamaah., Selain itu dengan peran para tokoh agama dan masyarakat bahu membau untuk bergotong royong semisal Ketika Renovasi Masjid, jamaah dan warga masyarakat dengan suka cita serta dengan semangat dalam membangun dan menjalin silaturahmi di antara jamaah satu dengan yang lainnya.

Hal tersebut diperkuat dengan penjelasan dari Bapak Syamsul Hadi, S.Ag. selaku ketua Takmir Masjid Nurul Huda Boto pada Hari Jum'at 06 November 2020 seperti berikut:

Kehidupan sosial kegamaan masyarakat di desa Boto dalam hal pendidikan agama masih tetap terjaga dengan baik. Walau dalam era globalisasi saai ini dan juga kecanggihan zaman, maka persatuan dan kebersamaan tetap terjaga. Kegiatan di masjid dan di musholamushola tetap istiqomah berjalan semisal kegiatan Taklim, kultum, yasin tahlil, dziba'an dan lain-lain. Selain itu; hal yang paling menjadi perhatian adalah ketika Pengurus atau Panitia pembangunan masjid mengumumkan untuk kerja bakti di masjid dengan sigap jamaah langsung berangkat. Bila ada salah satu warga atau jamaah yang meninggal dunia, maka mereka juga akan datang untuk takziyah,dan meninggalkan pekerjaan, dalam rangka untuk memberikan penghormatan terakhir. 
Tabel 4.1 Jadwal Kegiatan Keagamaan

\begin{tabular}{|c|c|c|c|c|}
\hline No. & Nama Kegiatan & Hari & Jam & Keterangan \\
\hline 1. & $\begin{array}{l}\text { Tahlil } \\
\text { a. Fatayat } \\
\text { b. Muslimat } \\
\text { c. Masjid Nurul } \\
\text { huda }\end{array}$ & $\begin{array}{l}\text { Selasa } \\
\text { Ahad } \\
\text { Kamis }\end{array}$ & $\begin{array}{l}18.30 \\
18.30 \\
19.00\end{array}$ & $\begin{array}{l}\text { Yasin, tahlil, istighotsah, } \\
\text { dziba', barzanji. }\end{array}$ \\
\hline 2. & Diniyah & $\begin{array}{l}\text { Sabtu } \\
\text { Ahad } \\
\text { Senin } \\
\text { Selasa } \\
\text { Rabu } \\
\text { Kamis }\end{array}$ & $\begin{array}{l}18.30 \\
18.30 \\
18.30 \\
18.30 \\
18.30 \\
18.30\end{array}$ & $\begin{array}{c}\text { Kitab Akhlak } \\
\text { Kitab Nahwu Shorof } \\
\text { Kitab Aqidah Islamiyah } \\
\text { Kitab Syifaul Janan } \\
\text { Pego } \\
\text { Dziba' }\end{array}$ \\
\hline 3. & TPQ & $\begin{array}{l}\text { Sabtu } \\
\text { Ahad } \\
\text { Senin } \\
\text { Selasa } \\
\text { Rabu } \\
\text { Kamis }\end{array}$ & $\begin{array}{l}14.00 \\
14.00 \\
14.00 \\
14.00 \\
14.00 \\
14.00\end{array}$ & $\begin{array}{c}\text { Aqidah } \\
\text { Fikih } \\
\text { Do'a Harian } \\
\text { Surat Pilihan } \\
\text { Ayat Pilihan } \\
\text { Pego dan Kaligrafi }\end{array}$ \\
\hline 4. & Remaja Masjid & $\begin{array}{l}\text { Jum'at Wage } \\
\text { Senin dan } \\
\text { Ahad }\end{array}$ & $\begin{array}{l}05.30 \\
18.15\end{array}$ & $\begin{array}{c}\text { Khataman Rutin di } \\
\text { Masjid Nurul Huda/ } \\
\text { Rumah Anggota Remas } \\
\text { Dziba' Rutin di Masjid } \\
\text { dan Musholla }\end{array}$ \\
\hline 5. & Pengajian Umum & Muharram & 19.00 & $\begin{array}{c}\text { Pengajian Umum di } \\
\text { Masjid Nurul Huda Desa } \\
\text { Boto }\end{array}$ \\
\hline 6 & Majlis Taklim & Setiap malam & 18.00 & Di Masjid Nurul Huda \\
\hline
\end{tabular}




\section{Peran Tokoh Agama dan Tokoh Masyarakat dalam Kehidupan Sosial Keagamaan Masyarakat di Desa Boto Kecamatan Semanding Kabupaten Tuban}

Pendidikan agama memang sangatlah penting kaitannya dalam kehidupan manusia baik untuk bekal di dunia maupun di akhirat, karena tanpa pendidikan agama hidup manusia akan mudah di ombang-ambing oleh zaman tanpa tahu tujuan yang pasti. Dengan berpedoman pada agama, diharapkan manusia dapat mengerti serta memahami diri dalam melaksanakan kehidupan di dunia, dan dengan pendidikan agama tersebut manusia akan memperoleh arti dalam menjalani hidup ini sesuai apa yang diperintahkan oleh sang Pencipta. Di sinilah Peran Tokoh Agama dan Masyarakat dalam kehidupan sosial keagamaan di desa Boto memiliki peran yang penting dalam kehidupan masyarakat antaranya sebagai berikut:

1). Peran Tokoh Agama dalam Membina Sikap Religius

2). Peran Tokoh Masyarakat untuk Membangun Etika Sosial

\section{Pembahasan}

Hingga saat ini dunia pendidikan pada umumnya dan pendidikan Islam pada khususnya masih menghadapi berbagai masalah yang belum dapat dipecahkan secara tuntas. Terbatasnya lahan, minimnya sarana prasarana yang tersedia, tawuran pelajar, pergaulan bebas, dan masih adanya anak usia sekolah yang belum mengenyam pendidikan atau putus sekolah adalah diantara permasalahan pendidikan tersebut. Agama merupakan suatu cara manusia menemukan makna hidup dan dunia yang menjadi lingkungannya. Tapi, hidup kita dan lingkungan abad modern ini semakin sulit diterangkan maknanya. Kesulitan itu terutama ditimbulkan oleh masalah-masalah yang muncul akibat dinamika ilmu pengetahuan dan teknologi. Pada abad modern, nilai berganti dengan cepat demikian pula dengan cara hidup masyarakat, dan memisahkan manusia semakin jauh dari nilainilai agama, inilah tantangan yang sedang dihadapi agama Islam.

Islam mengajarkan kepada umatnya bahwa akhirat pada dasarnya merupakan konsekuensi atau hasil dari perbuatan di dunia. Islam dengan sumber utamanya Al-Qur'an dan didampingi asSunnah diyakini berisi ajaran yang dapat membantu manusia dalam memberikan jawaban terhadap permasalahan yang terjadi akibat perubahan sosial. Hal ini karena nilai-nilai yang terdapat dalam ajaran Islam tersebut selain bersifat universal juga berlaku sepanjang zaman. Sedangkan tujuan pendidikan agama Islam menurut Daradjat (2018:29) adalah "sesuatu yang diharapkan terwujud setelah orang mengalami pendidikan Islam secara keseluruhan, yaitu kepribadian seseorang yang membuatnya menjadi 'insan kamil'”. Artinya pendidikan Islam diharapkan menghasilkan manusia yang berguna bagi dirinya dan masyarakat, serta senang mengamalkan ajaran Islam dalam 
berhubungan dengan Allah dan sesama manusia, dapat mengambil manfaat dalam menyikapi alam atau lingkungan dengan baik untuk kepentingan hidup di dunia dan di akhirat.

Selain itu, Islam juga memberikan petunjuk dan strategi dalam menghadapi perubahan sosial, yaitu dimulai dengan mengubah diri sendiri terlebih dahulu. Perubahan sosial dalam Islam dimulai dari perubahan pribadi masing-masing dan perubahan pribadi ini dimulai dari perubahan cara berpikir. Pengahayatan, ucapan dan perbuatan yang tampak merupakan gambaran dari pemikiran dan keyakinan. Hal ini juga dilakukan oleh Rasulullah SAW ketika berdakwah pada kaum jahiliyah, diketahui bahwa orang-orang jahiliyah di zaman Rasulullah bukanlah orang bodoh dalam arti tidak pandai, atau lainnya. Mereka disebut jahiliyah karena mereka salah dalam menerapkan pola pikir, mereka lebih memilih tujuan hidup jangka pendek daripada jangka panjang. Mereka lebih memilih harta, tahta dan kasta daripada memilih iman dan takwa.

Dengan usaha dakwah Nabi Muhammad SAW yang sangat sabar sehingga membuat masyarakat Arab dari Jahiliyah menjadi masyarakat muslim, karena agama Islam sebagai agama yang rohmatan lil 'aalamiin, sehingga masyarakat Jahiliyah tersebut sadar bahwa tujuan jangka panjang di akhirat adalah lebih baik daripada tujuan jangka pendek di dunia. Kehidupan dunia adalah amanah dari Tuhan dan akan diminta pertanggungjawabannya. Kehidupan di dunia adalah saat untuk menghimpun amal kebajikan untuk kehidupan di akhirat. Dengan tujuan hidup jangka panjang ini, maka manusia akan senantiasa melakukan amal kebajikan, tidak akan menghina atau memperbudak manusia ciptaan Allah, tidak akan menyembah segala sesuatu yang tidak mungkin dapat menyelamatkan hidupnya di dunia dan akhirat. Dengan pola pikir jangka panjang ini, maka tidak akan ada lagi sikap dzalim, meremehkan, atau menghina orang lain. Manusia akan sadar bahwa tahta, harta dan kasta adalah sesuatu yang bersifat sementara, bisa datang dan pergi, dan belum tentu menjamin keselamatan hidup manusia.

Masyarakat desa Boto sendiri termasuk masyarakat yang sudah mengenal banyak pendidikan. Namun yang peneliti anggap sebagai polemik adalah pandangan masyarakat terhadap pendidikan itu sendiri. Masyarakat Boto dahulu menganggap bahwa pendidikan tidak akan mampu menjamin kesejahteraan masa depan, sehingga banyak orang tua yang kurang menghiraukan pendidikan anak-anaknya, namun sekarang mindset masyarakat desa Boto sudah mulai berubah, masyarakat sudah sadar bahwa pendidikan sangatlah penting bagi kehidupan khususnya pendidikan agama Islam. Pada dasarnya masyarakat desa Boto sudah banyak dan sudah lama mengenal pendidikan, buktinya pada tahun 90-an sudah ada sebagian kecil masyarakat yang menyandang gelar sarjana. Ini membuktikan bahwa pendidikan sudah masuk ke dalam masyarakat Boto, dan sampai sekarang masyarakat juga masih antusias dalam mengikuti pengajian-pengajian umum dan banyak juga anak yang menimba ilmu di pondok pesantren. 
Pemikiran masyarakat dulu bahwa pendidikan agama kurang begitu penting, dengan alasan mendasar bahwa pendidikan agama tidak mampu menjadi sumber kehidupan atau pendidikan agama tidak dapat digunakan sebagai modal mencari penghasilan.

Menurut Daradjat (2018:28) "pendidikan Islam itu adalah pembentukan kepribadian muslim”. Dalam masyarakat tentu saja pendidikan agama Islam dapat membentuk kepribadian muslim, di desa Boto ini pembentukan kepribadian muslim atau pendidikan agama Islamnya terbentuk melalui kegiatan-kegiatan keagamaan yang sudah menjadi tradisi sejak lama. Menurut Fauzan (2000:76) "untuk mengatasi kekhawatiran dalam kehidupan, salah satu cara yang dapat ditempuh yaitu dengan mengoptimalkan pendidikan agama Islam

Manusia dalam hidupnya membutuhkan tiang untuk bersandar di saat kesengsaraan meliputinya, bencana menimpanya, menghadapi apa yang tidak disukainya atau bahkan gagal dalam mencapai apa yang diharapkannya, di sinilah peran agama hadir memberi sebuah kekuatan, harapan, kemauan, rasa optimis dalam hidup, serta memberi ketabahan di saat mengalami kesempitan dan penderitaan. Hidup manusia bagaikan lalu lintas, masing-masing ingin berjalan dengan selamat sekaligus cepat sampai ke tujuan. Namun, karena kepentingan mereka berbeda maka manusia membutuhkan rambu-rambu demi lancarnya lalu lintas kehidupannya agar tidak terjadi benturan dan tabrakan. Rambu-rambu tersebut memberi manusia petunjuk seperti kapan harus berhenti, kapan harus hati-hati dan kapan bisa berjalan dan sebagainya. Peran pendidikan agama dalam kehidupan suatu masyarakat atau bangsa, bukan sekedar sebagai alih pengetahuan dan keterampilan saja, tetapi seharusnya juga sebagai kegiatan alih nilai dan budaya. Oleh karena itu, Hasan (2005:174) menjelaskan bahwa "setiap konsep pendidikan atau strategi pendidikan bukan semata-mata usaha untuk menyiapkan manusia yang pandai atau terampil, tapi juga manusia yang berkepribadian dan berbudaya".

Untuk kelengkapan pembahasan ada baiknya melanjutkannya dengan sejenak melihat prospek religiusitas dalam suatu masyarakat,

Pada dasarnya tujuan hidup manusia adalah memperoleh kebahagiaan di dunia dan akhirat, sementara kewajiban atau tugas hidup manusia menurut Al-Qur'an adalah mengabdi atau beribadah kepada Allah. Menurut Supadie, dkk. (2015:184) menyatakan bahwa "manusia diciptakan Allah tidak lain adalah agar mengabdikan dirinya kepada-Nya". Allah berfirman dalam QS. Adz-Dzariyat [51] ayat 56 :

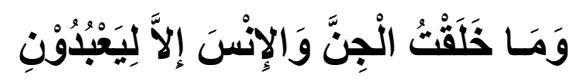

Artinya : Aku ciptakan jin dan manusia kecuali untuk mengabdi kepadaku (QS. Adz-Dzariyat [51]: $56)$. 
Kandungan ayat tersebut di atas adalah menjelaskan bahwa manusia diciptakan untuk beribadah pada Allah SWT. Menjalankan segala perintah-Nya dan menjauhi segala larangan-Nya. Segala apapun yang manusia kerjakan harus sesuai dengan aturan agama, termasuk dalam hal pendidikan. Bagaimanapun pendidikan itu akan dikembangkan harus sesuai dengan koridor keislaman. Di dalam Islam terdapat banyak hal yang mengatur kehidupan, dengan tujuan agar manusia tidak bertindak sesuka hatinya. Kapanpun manusia hidup dan dimana pun kita berada, agama tetap merupakan kebutuhan seseorang. Di abad modern sekarang ini, agama tetap diperlukan. Semakin jauh manusia mencapai kemajuan, semakin memerlukan agama. Tanpa agama, setiap kemajuan belum tentu membahagiakan manusia, malah mungkin membinasakan manusia. Dengan demikian peran pendidikan agama Islam dalam kehidupan manusia sangatlah penting agar kehidupan di masyarakat tidak melenceng dari ajaran agama.

1). Peran Tokoh Agama dalam Membina Sikap Religius

Tokoh Agama di desa Boto ini berperan sebagai pelopor pembinaan sikap religius. Sikap religius merupakan bagian penting dari kepribadian seseorang, moral merupakan keterikatan spiritual pada norma-norma yang telah ditetapkan, baik yang bersumber pada ajaran agama, budaya masyarakat atau berasal dari tradisi berfikir secara ilmiah. Keterikatan spiritual tersebut akan memengaruhi keterikatan sikapnya terhadap nilai-nilai kehidupan (norma) yang akan menjadi pijakan utama dalam menetapkan suatu pilihan dalam menetapkan suatu tindakan. Keterikatan pada norma-norma religius akan membentuk sikap tertentu dalam menyikapi segala persoalan. Sikap religius yang terbentuk dari keterikatan yang kuat pada norma-norma yang diterapkan oleh agama akan menjadikan seseorang dapat mengukur kebenaran suatu hal dari sudut pandang agama. Di desa Boto misalnya jarang sekali terdengar adanya kasus pencurian, ataupun tawuran antar masyarakat. Ini berarti masyarakat desa Boto orientasi moralnya masih dapat terjaga sehingga peristiwa yang melenceng dari tata nilai masyarakat sangat jarang ditemui, sehingga kesejahteraan dalam kehidupan sosial dapat terus lestari.

Pendidikan agama Islam di desa Boto juga membina sikap religius sebagai internalisasi agama. Internalisasi nilai agama ini di sini merupakan suatu proses memasukkan nilai agama secara penuh ke dalam hati, sehingga bergerak berdasarkan ajaran agama. Internalisasi nilai agama terjadi melalui pemahaman ajaran agama secara utuh, dan diteruskan dengan kesadaran akan pentingnya ajaran agama untuk merealisasikannya dalam kehidupan nyata. Hal ini telah dipaparkan oleh bapak H. Nafi'udin bahwa seberapa banyak dan seberapa jauh nilai-nilai agama bisa memengaruhi dan membentuk sikap serta perilaku seseorang sangat tergantung dari seberapa dalam nilai-nilai agama tertanam dalam dirinya. Semakin dalam nilai-nilai agama tersebut tertanam dalam diri seseorang, kepribadian dan sikap religiusnya akan muncul dan terbentuk nyata dalam kehidupan 
bermasyarakat. Jika sikap religius sudah muncul dan terbentuk, maka nilai-nilai agama akan menjadi pusat nilai dalam menyikapi segala sesuatu dalam kehidupan. Dengan pemahaman nilai agama yang baik, seseorang akan terbimbing pola pikir, sikap dan segala tindakan yang diambilnya.

Pendidikan agama Islam memegang peranan penting dalam menata kehidupan manusia, baik dalam penataan hidup pribadi maupun penataan hidup bersama dalam hidup bermasyarakat. Untuk kepentingan pribadi, agama berfungsi sebagai sarana untuk menyalurkan fitrah keberagamaannya sehingga rasa keberagamaannya itu berkembang secara lurus, dengan cara itu maka perasaan damai dan kepuasan batin akan diperoleh. Di sinilah agama berperan sebagai etos kerja. Untuk penataan kepentingan hidup bersama, agama berisi seperangkat ajaran tentang bagaimana seseorang seharusnya menempatkan diri, berinteraksi dan berperilaku terhadap orang lain. Agama memberikan bimbingan kepada individu dalam mengembangkan keterampilan sosialnya, keterampilan sosial ini terakomodasi dalam interaksi kehidupan bersama. Oleh sebab itu, agama sebagai sumber etos kerja, bagi seseorang pemeluk agama, etos kerja muncul dari dorongan sikap yang terbentuk oleh nilai-nilai agama. Sebagai etos kerja, sikap religius memberikan dorongan kepada seseorang dalam mencari makna religius bagi tindakan yang dipilihnya. Sehingga masyarakat desa Boto yang memiliki pendidikan agama yang baik pasti menyerahkan semua yang dilakukan atau mencari pekerjaan dengan berniat untuk dapat menghidupi keluarga dengan jalan halal, dari cara ini pendidikan agama berperan sebagai etos kerja. Dan masyarakat yang biasanya mempunyai pendidikan agama yang baik dapat menjadi panutan, misalnya ; menjadi imam masjid, imam mushola, ketua jamaah yasin tahlil, pengurus UPZ dan lainnya inilah yang dimaksud keterampilan sosial kegamaan. Dengan demikian, tindakan dan perbuatan yang dilakukannya tidak lagi dirasakan sebagai beban, melainkan sebagai sumber kepuasan batiniyah.

\section{2). Peran Tokoh Masyarakat dalam Membangun Etika Sosial}

Selain sebagai pelopor dalam pembinaan sikap religius, Tokoh Masyarakat di desa Boto juga berperan untuk membangun etika sosial. Akhir-akhir ini kita masih sering disuguhi peristiwa kurangnya rasa menghormati, pesta minuman keras dan lain sebagainya. Peristiwa ini bukan hanya fenomena kota besar seperti di surabaya, gresik, malang, bahkan jakarta, tetapi sudah merambah ke kota-kota kecil dan tidak terlewatkan kabupaten tuban bahkan sudah merambah ke kampungkampung atau pedesaan. Dalam lingkungan masyarakat pun sering kita jumpai bahwa dalam tingkah laku sehari-harinya saja terkadang orang tua apalagi anak-anaknya ini sering menggunakan bahasa-bahasa jorok yang tidak pantas digunakan, sikap yang semakin jauh dari nilai-nilai agama, sifat malu seakan mulai pudar dilihat dari maraknya orang yang gemar main tiktok mulai dari kalangan anak kecil sampai orang dewasa. Dengan hadirnya tokoh agama dan tokoh masyarakat mudah-mudah mampu berperan untuk mengajarkan budi pekerti, namun realitasnya memang 
sekarang ini kualitasnya semakin menyusut, seiring dengan perkembangan zaman. Fenomena ini semakin menjadi-jadi di lingkungan masyarakat, dengan pendidikan agama yang baik, maka masyarakat juga akan berpikir dua kali untuk melakukan hal yang seperti tadi dan akan lebih menjaga budi pekertinya dalam kehidupan agar tidak merugikan dirinya sendiri apalagi orang lain, di sinilah peran togamas dalam mengajarkan dan menyampaikan ajakan kebaikan lewat mimbar khutbah, majlis taklim atau forum-forum di lingkungan masyarakat desa boto yaitu tentang pentingnya budi pekerti dalam kehidupan social keagamaan bermasyarakat. Di dalam masyarakat desa Boto, secara umum masyarakatnya cukup baik karena juga jarang ditemui peristiwa yang melenceng dari agama, misalnya tawuran dan lainnya.

Kita juga sering disuguhi pemandangan yang kurang menyenangkan disebabkan oleh ulah manusia sendiri, suka membuang sampah sembarangan, membuang sampah ke sungai dan lain sebagainya, tanpa menyadari bahwa hal itu membahayakan dapat merusak lingkungan. Etika lingkungan dengan segala aspek hendaknya kita masyarakatkan dalam rangka menjaga kelangsungan hidup umat manusia yang menjunjung tinggi nilai-nilai etika dalam rangka menciptakan kesejahteraan bersama. Misalnya di desa Boto juga biasanya mengerjakan kerja bakti di lingkungan. Dengan membangun etika lingkungan yang baik, maka masyarakat akan sadar bahwa selain manusia, hewan, tumbuhan dan lainnya juga memiliki kehidupan dan dengan pendidikan agama yang baik, maka kita akan bisa membangun etika yang baik pula dalam lingkungan, misalnya dengan menjaga kebersihan dan lainnya.

Berdasarkan pembahasan tersebut di atas, maka peneliti dapat mengambil kesimpulan bahwa dalam penelitian ini peran togamas dalam kehidupan sosial keagamaan desa Boto sangatlah berperan penting yaitu untuk menjadi pelopor membina sikap religius dan membangun etika sosial. Dalam perannya sebagai pembinaan sikap religius ini diantaranya yaitu sikap religius sebagai orientasi moral, internalisasi nilai agama, dan sikap religius sebagai etos kerja serta keterampilan sosial. Sedangkan peran yang ke dua yaitu pendidikan agama Islam untuk membangun etika sosial, yaitu dalam mengajarkan budi pekerti dalam lingkungan sosial, membangun etika lingkungan yang baik dan mengajarkan respek dan tanggung jawab dalam kehidupan bermasyarakat.

\section{PENUTUP}

\section{Kesimpulan}

Berdasarkan hasil analisis yang sudah diperoleh, maka peneliti dapat menarik kesimpulan sebagai berikut :

1) Peran togamas (tokoh agama dan masyarakat) dalam kehidupan sosial keagamaan masyarakat desa Boto, kalau dilihat secara umum sudah cukup baik. Hubungan sosialnya juga masih 
terjaga, dengan perkembangan zaman seakan tidak melunturkan ciri khas masyarakat tradisional yang ada di desa Boto ini. Tradisi masyarakat khususnya berkenaan dengan keagamaan juga masih terjaga dengan baik. Masyarakat tetap ramah terhadap sesama, suka tolong-menolong, dan juga masih sangat antusias dalam mengikuti kegiatan keagamaan dan kegiatan sosial yang ada di masyarakat. Dari pendidikannya juga semakin maju, terlihat semakin banyaknya masyarakat yang melanjutkan studinya di perguruan tinggi maupun di pondok pesantren dan jarang dijumpai anak yang putus sekolah. Dari segi perekonomian masyarakat boto memiliki berbagai macam profesi, di antaranya PNS, petani, peternak, pedagang, karyawan, guru dan lain-lain. Di desa boto sendiri juga memiliki icon desa penghasil legen, ental dan lain-lain

2) Peran togamas (tokoh agama dan masyarakat) dalam kehidupan sosial masyarakat desa Boto sangatlah berperan penting yaitu menjadi pelopor dan penggerak untuk memberikan pembinaan sikap religius dan membangun etika sosial. Dalam perannya sebagai pembinaan sikap religius ini diantaranya yaitu sikap religius sebagai orientasi moral, internalisasi nilai agama, dan sikap religius sebagai etos kerja serta keterampilan dalam kehidupan sosial keagamaan masyarakat.

\section{Saran}

Dengan terselesaikannya artikel ini, maka peneliti memberikan saran kepada beberapa pihak di antaranya tokoh agama dan masyarakat untuk selalu mendampingi dan mengajak untuk mengamalkan ajaran agama dan menjaga masyarakat desa Boto agar tetap guyub dan rukun untuk menuju masyarakat adil, makmur dan sejahtera. Agar kehidupan sosial kegamaan bisa berjalan dengan baik dan hubungan antara ulama, umaro dan masyarakat menjadi satu kesatuan dalam nilainilai kebersamaan.

\section{DAFTAR RUJUKAN}

Anwar, Rosihon, dkk,. 2017. Pengantar Studi Islam. Bandung: CV. Pustaka Setia.

Ariyanto, Yudi. Rinwanto, 2019. Aspek Ritual Dan Sosial Dalam Tipologi Perilaku Keberagamaan Masyarakat. Volume 13 No.01 (2019) Tadris: Jurnal Penelitian dan Pemikiran Pendidikan Islam http://ejournal.iainutuban.ac.id/index.php/tadris/issue/view/8. di akses 22 Desember 2020

Arsyad, Muh. 2019. Upaya Mewujudkan Masyarakat Madani. Al-Musannif: Journal of Islamic Education and Teacher Training, (Online), Vol 1, No. 1,(https://jurnal.mtsddicilellang.sch.id/index.php/al-musannif/article/view/9. diakses 15 Desember 2019).

Daradjat, Zakiah. 2018. Ilmu Pendidikan Islam. Jakarta: Bumi Aksara. 
Fauzan, Mochamad. 2000. Digital Library UIN Sunan Ampel, 2016: Peranan Pendidikan Agama Islam bagi Kehidupan Masyarakat di Kecamatan Bangil Kabupaten Pasuruan, (Online),(http://digilib.uinsby.ac.id/4316/, diakses 26 Desember 2019).

Hasan, Muhammad Tholhah. 2005. Islam dan Masalah Sumber Daya Manusia. Jakarta: Lantabora Press.

Herdiana, Nina Arie. (2016, 22 Februari). Islam dan Kehidupan Sosial. Dikutip 27 Desember 2019 dari Blogmue Blogspot: https://blog-mue.blogspot.com/2016/02/makalah-islam-dalamkehidupan-sosial.html.

Karsadi. 2018. Metodologi Penelitian Sosial. Yogyakarta: Pustaka Pelajar.

Kaelany HD.2009. Islam Agama Universal. Jakarta: Midada Rahma Press

Khair, Muh Afiful. (2013, 2 Desember). Restorasi Peran Pendidikan Islam dalam Tatanan Kehidupan Sosial. Dikutip 15 Desember 2019 dari Ejurnal IAIN Madura: https://ejurnal.iainmadura.ac.id

Khoiriyah. 2014. Sosiologi Pendidikan Islam. Yogyakarta: Teras.

LP3M STITMA. 2019. Pedoman Penelitian Skripsi dan Karya Ilmiah. Tuban: STITMA Press.

Moleong, Lexy J. 2017. Metode Penelitian Kualitatif. Bandung: P.T. Remaja Rosdakarya.

Nasution, S. 1995. Sosiologi Pendidikan. Jakarta: Bumi Aksara.

Riadi, Dayun, dkk,. 2017. Ilmu Pendidikan Islam. Yogyakarta: IAIN Bengkulu Press.

Soekanto, Soerjono. 2010. Sosiologi Suatu Pengantar. Jakarta: P.T. Raja Grafindo Persada.

Subarkah, Andi. Dkk. 2012. Al-Qur'an dan Terjemah New Cordova. Bandung: Syamil Qur'an

Supadie, Didiek Ahmad,.dkk. 2015. Pengantar Studi Islam. Jakarta: P.T. Raja Grafindo Persada.

Supardan, Dadang. 2015. Pengantar Ilmu Sosial. Jakarta: P.T. Bumi Aksara

www.boto-semanding-desa.id. 